\title{
Characterization of an Alfisol Collected from Dry Zone of Sri Lanka to Elucidate the Retention Mechanisms of Pollutants
}

\author{
U.K.P.S. Sanjeevani, S.P. Indraratne ${ }^{1 *}$, S.V.R. Weerasooriya and W.A.U. Vitharana \\ Postgraduate Institute of Agriculture \\ University of Peradeniya \\ Sri Lanka
}

\begin{abstract}
Characterization of physicochemical properties of a soil enables predicting the behavior of nutrients and pollutants added to the soil. A study was conducted to characterize environmentally important physicochemical properties and processes of an Alfisol (Reddish Brown Earth) collected from the Dry zone of Sri Lanka. Organic carbon content (OC), pH, Electrical Conductivity of soil suspension (EC) and saturated paste (ECe), Cation Exchange Capacity (CEC), and available and total metals $(\mathrm{Cu}, \mathrm{Zn}$ and $\mathrm{Cd})$ were analyzed. Potentiometric titration and adsorption study were conducted to determine the Point of Zero Charge (PZC) and phosphorus adsorption capacity of the soil. Clay mineralogy of the soil was determined using X-ray diffraction technique. Among the basic soil chemical properties analyzed, CEC (13.2 $\left.\mathrm{cmol}_{+} \mathrm{kg}^{-1}\right)$ showed a low cation retention attributed to low organic carbon percentage (mean $0.37 \%$ ) and the predominating of lowactivity clay minerals of kaolinite and illite. The EC values (EC=0.03 $\mathrm{dS} \mathrm{m}^{-1}, E C e=0.3$ $\left.d S \mathrm{~m}^{-1}\right)$ indicated a low salinity level. Point of zero charge of the soil was 4.0 indicating net negative charges at the existing soil pH of 6.37. At the near neutral pH of the soil, the cation retention enhanced, subsequently affecting the mobility of metals. Phosphorus adsorption data fitted to Langmuir isotherm gave an adsorption maximum of $14285 \mathrm{mg} \mathrm{kg}^{-1}$ indicating a high $P$ fixing ability. The soil properties studied can be used to elucidate the retention mechanisms of pollutants in this soil.
\end{abstract}

Keywords: Physicochemical properties, clay mineralogy, phosphorus adsorption, point of zero charge.

\section{INTRODUCTION}

The Alfisol Catena is the most extensive soil association in Sri Lanka covering 2.5 million ha and has the greatest potential for agricultural crop production (Dimantha, 1994). Well drain Reddish Brown Earth (RBE) soils (Rhodustalfs) occur on the crests and upper slopes of the dry zone catena (Somasiri, 1984). Further, a larger proportion of Sri Lanka's agriculture is confined to the Dry zone. With the green revolution and introduction of newly improved crop varieties intensive agricultural practices have been adopted by farmers. Long term adaptation of such practices alter the basic chemical properties of soil such as soil $\mathrm{pH}$ (Simek et al., 1999), organic matter content (Manna et al., 2005), cation exchange capacity (CEC) (Zhao and Zhang, 1997) soil nitrogen (Simek et al., 1999), phosphorus and potassium

Department of Soil Science, Faculty of Agriculture, University of Peradeniya, Sri Lanka

Corresponding author: srimathii@pdn.ac.lk 
contents (Parham et al., 2002). Further, many researchers have revealed that trace metals such as Cadmium, Zinc, Copper and Arsenic contents in soil can increase as they are found in most of the synthetic fertilizers and agrochemicals such as pesticides and herbicides as impurities or active ingredients (McLaughlin et al., 2000, Ajayi et al., 2012). Metals transfer from soil to other ecosystem components such as groundwater and crops is one of the most important sources of trace metal contamination of humans. This can be a threat to human health due to their persistence and toxicity (Mico et al., 2006). Research conducted in intensive agricultural areas evidenced presence of elevated trace metal levels. Premarathne et al., (2010) reported elevated amount of some trace elements in intensively vegetable grown wet zone fields in Sri Lanka.

Since clay mineral inter-phase plays a major role in metal transport and cycling through the geosphere, electrochemical properties of clay mineral surfaces are important in environmental and geochemical studies (Sinitsyn et al., 1999). Soil colloid surfaces can bare permanent and variable charges. These variable charges can be net negative, positive or zero charge depending on the soil $\mathrm{pH}$. This amphoteric character is important in soil nutrient management and retention of soil contaminations (Naindu et al., 1997). The $\mathrm{pH}$ at which the net total particle charge is zero is called the point of zero charge (PZC), which is one of the most important parameters used to describe variable charge surfaces (Morais et al., 1976). The PZC governs the ion exchange, adsorption and other chemical processes occurring at the liquid colloid inter-phase. Such reactions control physicochemical properties of ions and affects soil-water-plant ecosystems, specially retention of metal on the soil surface (Karak et al., 2005). Among the different methods for the determination of the PZC in different materials, soil researches generally rely on potentiometric titration. This method determines the point of zero salt effect (PZSE) which assesses changes in surface potential with changes in the activities of $\mathrm{H}^{+}$and the $\mathrm{OH}^{-}$(Appel et al., 2003). Point of zero salt effect value can be used to explain the mechanisms associated with specific adsorption of cations $\left(\mathrm{Ca}^{2+}, \mathrm{Cu}^{2+}\right.$, $\left.\mathrm{Pb}^{2+}, \mathrm{Zn}^{2+}\right)$ and the anions $\left(\mathrm{F}^{-}, \mathrm{PO}_{4}^{-3}, \mathrm{SO}_{4}{ }^{-2}\right)$ which can modify the proportion between the negative and positive surface charge of the soil (Yu et al.,1997 and Zhao \& Zhang, 1997). Further difference of PZSE and $\mathrm{pH}$ jointly affect the degree of flocculation of the soil particles and consequently, the water dynamics, gas transfer and susceptibility to erosion losses (Alves and Lavorenti, 2005).

Adsorption is the mechanism commonly responsible for the retention of ions and molecules, particularly trace element cations, anions and organic compounds by soil (Essington, 2003). Tan (1994) revealed that the soil phosphorous fixation reactions may allow only a small fraction (10 to $15 \%)$ of the phosphorus in fertilizer to be taken up by plants. Meantime, farmers apply two to four times more quantities of phosphorus as it would be removed as crop harvest. Repeating such practices over many years will saturate the phosphorus fixation capacity and build up the level of available phosphorus in agricultural soils (Daniel et al., 1998). The accumulation and transfer of phosphorus in intensive farming systems has increased phosphorus export from agricultural watersheds and accelerated eutrophication of surface water (Sharpley and Tunney, 2000). Phosphorus retention capacity was found to be a measure of the ability of soil to retain $\mathrm{P}$, and an important factor controlling the release of $\mathrm{P}$ from soil to water (Akinremi et al., 2007). Hence, characterization of a soil with respect to environmentally important physicochemical properties is important to maximize the crop production while minimizing environmental pollution. Therefore, objective of this study was to characterize the selected Alfisol (RBE) with respect to environmentally important physicochemical soil properties and processes to understand the retention behavior of inorganic pollutants at colloidal inter-phase. 


\section{MATERIALS AND METHODS}

\section{Soil sampling and analysis of basic chemical properties}

Soil sample was collected from the Field Crop Research and Development Institute, Mahailluppallama at $08^{0} 06.713^{\prime} \mathrm{N}, 80^{\circ} 28.353^{\prime} \mathrm{E}$ located within DL1 agro ecological region in the dry zone of Sri Lanka. According to the records, the selected location was not cultivated for about four years. Three sub samples were collected to the depth of 0-30 cm to obtain a composite sample representing well drain RBE soil. Soil sample was air dried and passed through $2 \mathrm{~mm}$ sieve prior to laboratory analysis. The physiochemical properties measured were organic carbon, pH, Electrical Conductivity (EC), Cation Exchange Capacity (CEC), and total and available concentrations of $\mathrm{Cu}, \mathrm{Zn}$ and $\mathrm{Cd}$. Organic carbon percentage was determined according to method described by Nelson and Sommer (1996). Soil pH was measured by using digital $\mathrm{pH}$ meter in both water and $1 \mathrm{M} \mathrm{KCl}$ solution having 1:2.5 soil: solution ratio. Electrical conductivity meter was used to measure the EC in 1:5 soil water suspensions and ECe in saturated paste. Ammonium acetate $(\mathrm{pH}=7)$ extraction was used to determine the cation exchange capacity (CEC) as described by Summer and Miller (1996).

\section{Extraction of metals}

Total metal contents were determined according to the method proposed by Sposito et al., (1982). In this method soils were digested with $4 \mathrm{M} \mathrm{HNO}_{3}$ at $80^{\circ} \mathrm{C}$ for four hours. Metal contents in filtered samples were measured using Atomic Absorption Spectrophotometer. Metals associated with all the pools except structural components are extracted by the nitric acid-digested procedure. Available metal contents were determined using DTPA at $\mathrm{pH} 7.3$ and $1 \mathrm{M} \mathrm{HCl}$ (Bandara, 2007).

\section{Point of zero charge determination}

Potentiometric titration method was used to determine the PZSE using $0.1 \mathrm{M}, 0.01 \mathrm{M}$ and $0.001 \mathrm{M} \mathrm{KCl}$ as described by Appel et al. (2003). Soil sieved through $0.5 \mathrm{~mm}$ was used. Soil was washed with $0.001 \mathrm{M} \mathrm{HCl}$ and air dried prior to the analysis. Ten milliliters of electrolyte solution was added to four grams of soil. Deionized water was used to make $25 \mathrm{~mL}$ of final volume. Soil $\mathrm{pH}$ was adjusted to a range between 2 and 8 with measured amount of $0.1 \mathrm{M}$ $\mathrm{HCl}$ and $0.1 \mathrm{M} \mathrm{KOH}$. After seven days of incubation period soil $\mathrm{pH}$ was measured in each suspension.

\section{Clay mineralogy analysis}

Pretreatments for the clay mineralogy analysis were done according to the method described by Kunze and Dixon (1986). Removal of soluble salts, organic matter and iron oxides were done prior to the clay fraction separation. Diffractograms were obtained between $2-30^{\circ} 2 \theta$ from $\mathrm{K}-, \mathrm{Mg}$ - saturated and Glycerol solvated clay samples. X-ray diffraction test was carried out by the Bruker FD800 Diffractrometer (Germany) operated at the potential of 40 $\mathrm{kV}$ and the amperage of $30 \mathrm{~mA}$, producing $\mathrm{Cu} \mathrm{K} \alpha$ radiation at a wave length of $1.54 \AA$ equipped with Ni filter and silicon monochromator. The diffractrograms were obtained using a continuous scanning technique at the speed of $0.02^{0}$ per second. 


\section{Phosphorus adsorption study}

Phosphorus adsorption study was conducted using $10 \mathrm{gL}^{-1}$ soil and $0.01 \mathrm{M} \mathrm{KCl}$ as background electrolyte at $\mathrm{pH}$ 5.4. Six concentration levels $\left(0,25,50,100,150 \mathrm{mg} \mathrm{P} \mathrm{L}^{-1}\right)$ of phosphorus and soils sieved by $0.5 \mathrm{~mm}$ were used for the study. Ten $\mathrm{mL}$ of $0.01 \mathrm{M} \mathrm{KCl}$ solutions containing $0,25,50,100$ and $150 \mathrm{mg} \mathrm{P} \mathrm{L}^{-1}$ were added to soil. Solution $\mathrm{pH}$ was adjusted to 5.4 using $0.1 \mathrm{M} \mathrm{HCl}$ and $0.1 \mathrm{M} \mathrm{KOH}$ as required and samples were shaken for 30 minutes and incubated for 24 hours at $29^{\circ} \mathrm{C}$. After centrifugation, suspension was filtered and phosphorus concentration was determined colorimetrically using the molybdenum blue method. The phosphorus adsorption maximum was obtained fitting to the Langmuir equation, after checking conformity.

\section{RESULTS AND DISCUSSION}

Organic carbon content is one of the most important soil properties affecting the physical, chemical and biological properties. Mean organic carbon content of the soil was $0.37 \%$ (Table 1) indicating very low organic carbon content in the soil. Low soil organic carbon contents are common for tropical soils. Kumaragamage and Kendaragama (2010) also discussed the necessity of proper organic matter management practices for dry zone soils in order to improve the nutrient retention in soil. Poor organic carbon content also resulted in low CEC value $\left(13.2 \mathrm{cmol}_{+} \mathrm{kg}^{-1}\right)$ indicating a moderate cationic nutrient retention in the soil. It suggests that soil fertility improvements could be done by addition of organic materials in this studied reddish brown earth soil in the dry zone of Sri Lanka. Soil sample showed a pH value of 6.37 confirming the value of 6.4 reported by Kumaragamage and Kendaragama (2010) for reddish brown earth soil in this area. Electrical conductivity gives an idea about the soluble salt content in soil. Presence of high amount of soluble salts in the soil is a major constraint limiting crop growth and yield in many of the soil series of the dry zone (Kumaragamage and Kendaragama, 2010). However the measured EC and ECe values indicated low amount of soluble salts in soil.

Table 1. Some important basic soil properties measured in the studied soil

\begin{tabular}{lc}
\hline Soil property & Value $^{*}$ \\
\hline Organic Carbon & $0.37 \%$ \\
Soil pH (1:2.5, distilled water) & 6.37 \\
Soil pH (1:2.5, M KCl) & 5.29 \\
EC (suspension) & $0.03 \mathrm{dS} / \mathrm{m}$ \\
EC (saturated paste) & $0.3 \mathrm{dS} / \mathrm{m}$ \\
CEC & $13.2 \mathrm{cmol} / \mathrm{kg}$ \\
Clay \% & 24.31 \\
Textural class & Sandy clay loam \\
\hline *values are average of three replicates &
\end{tabular}


Sources of trace metals in soil are mainly due to industrial and agricultural activities and natural metal deposits. Dry zone of Sri Lanka is not currently engaged in industrial activities at commercial levels and natural metal deposits are not reported (Indraratne, 2009)

Therefore, agricultural practices could be the main source to the trace metal accumulation in dry zone soils. Measured total and available metal contents are presented in Table 2.

Table 2. Available and total concentrations of $\mathrm{Cu}, \mathrm{Zn}$ and $\mathrm{Cd}$ measured in the studied soil

\begin{tabular}{lcccccccc}
\hline \multicolumn{2}{c}{$-------\mathrm{Cu}\left(\mathrm{mg} \mathrm{kg}^{-1}\right)------$} & \multicolumn{2}{c}{$------\mathrm{Zn}\left(\mathrm{mg} \mathrm{kg}^{-1}\right)-------$} & \multicolumn{3}{c}{$------\mathrm{Cd}\left(\mathrm{mg} \mathrm{kg}^{-1}\right)-------$} \\
DTPA & $1 \mathrm{MHCl}$ & total & DTPA & $1 \mathrm{MHCl}$ & total & DTPA & $1 \mathrm{MHCl}$ & total \\
\hline 0.64 & 3.06 & 8.84 & 1.08 & 3.58 & 20.85 & 0.03 & 0.09 & 0.16 \\
\hline
\end{tabular}

Cadmium is one of the trace elements that accumulate in plants to high concentrations that cause toxicity in animals but have no effect on plant growth. Whereas $\mathrm{Cu}$ and $\mathrm{Zn}$ show phytotoxicity at concentrations much lower than those that affect humans negatively (Chaney, 1973). Therefore, Cd has a hidden toxicity. Cadmium is present in fertilized soils as a divalent cation $\left(\mathrm{Cd}^{2+}\right)$ and associated with organic (Cd-dissolved organic carbon) and inorganic complexes (Stacey et al., 2010). Observed total metal concentrations were below the regulatory limits given by the European community for agricultural soils. European community set standards for $\mathrm{Cu}, \mathrm{Zn}$ and $\mathrm{Cd}$ as $50-140 \mathrm{mg} \mathrm{kg}^{-1}, 150-300 \mathrm{mg} \mathrm{kg}^{-1}$ and 1-3 mg $\mathrm{kg}^{-1}$, respectively (McGrith and McCormack, 1999). Assessing of different fractions of soil metals other than total metal content is important in predicting the availability and mobility of trace metals in soils (Kabata -Pendias and Pendias, 2001). Available ( $\mathrm{HCl}$ and EDTA extractable) metals also showed low concentrations indicating that the soil is not contaminated. Further, DTPA extractable fraction is lower than the $1 \mathrm{M} \mathrm{HCl}$ exchangeable fraction. Tu., et al. (2000) found that organic bound metal fraction is positively correlated with soil organic matter content. Therefore, low organic matter in the soil (Table 1) could be a reason for the lower concentration of available $\mathrm{Cd}, \mathrm{Cu}$ and $\mathrm{Zn}$.

\section{Clay mineralogy analysis}

X-ray diffractogram of the clay fraction of the Alfisol is shown in Fig. 1 A peak at $10.01 \AA$ in $\mathrm{K}$-saturated, $\mathrm{Mg}$ saturated and $\mathrm{Mg}$-Glycerol solvated samples respectively evidenced the presence of illite. Presence of kaolinite signified the peaks at $7.23 \AA$ in $\mathrm{K}$-saturated and $\mathrm{Mg}$ saturated samples. The bulge at 18.2 $\AA$ with glycerol treatment indicates the presence of montmorillonite as minor clay mineral. 

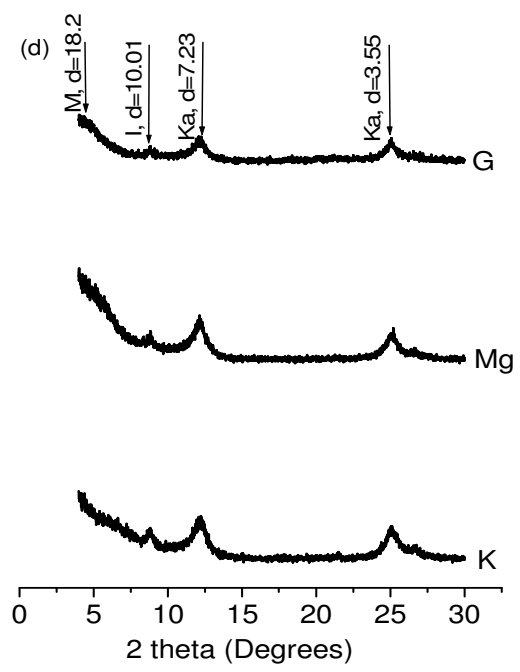

Fig. 1 X-ray diffractogram of the clay fraction of RBE soil (Ka= Kaolinite, I= Illite, $\mathrm{M}=$ montmorillonite, $\mathrm{K}=\mathrm{K}$-saturated, $\mathrm{Mg}=\mathrm{Mg}$ saturated, $\mathrm{G}=$ Glycerol solvated).

This confirmed illite and kaolinite are the dominant clay mineral while montmorillonite is the minor clay mineral in soil clay fraction of this Alfisol (Indraratne, 2010). Therefore, it is evident that the contribution of kaolinite for the surface charge development is significant for this soil. Further, dominance shown by kaolinite and illite could be the reason for low CEC in this studied soil.

\section{Point of zero charge determination}

The PZSE is the $\mathrm{pH}$ where the net adsorption of potential determining ions, $\mathrm{H}^{+}$and $\mathrm{OH}^{-}$, on variable charge surfaces and is independent of electrolyte concentration (Appel et al., 2003). Figure 2 shows the potentiometric titration curves at varying electrolyte concentrations $(0.1$, 0.01 and $0.001 \mathrm{M} \mathrm{KCl}$ ). Asymmetric charge behavior was observed (Fig. 2) indicating the heterogeneous nature of soil. Apparently two intersecting points were observed in this heterogeneous soil colloidal system in contrast to pure inorganic colloids. The titration curves for 0.01 and $0.001 \mathrm{M} \mathrm{KCl}$ showed an intersecting point at $\mathrm{pH} 6.9$ which is above the line of charge symmetry. Whereas titration curves for 0.1 and $0.01 \mathrm{M} \mathrm{KCl}$ showed an intersecting point at $\mathrm{pH} 4.0$ which is bellow the line of charge symmetry. The appearance of multi intersections of the titration curves is indicative of the activation of different soil surface sites for proton transfer. 


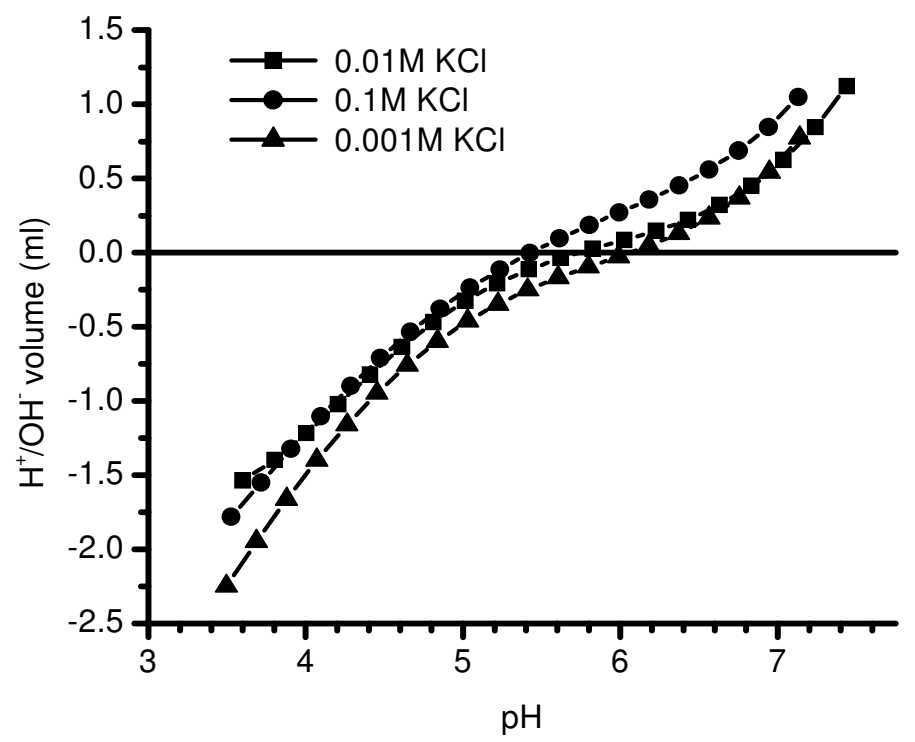

Fig. 2. Potentiometric titration curves for the studied soil at different electrolyte concentrations.

If the soil $\mathrm{pH}$ is above PZC, soil surfaces have a net negative charge and exhibit ability to exchange cations. If its $\mathrm{pH}$ is below its $\mathrm{PZC}$, soil will mainly retain anions. The difference of $\mathrm{pH}$ measured between $\mathrm{KCl}$ and distilled water can provide a good estimation of the net surface charge of soils (Alves and Lavorenti, 2005). In this Alfisol where $\mathrm{pH}$ is 6.37, the difference of $\mathrm{pH}$ in $\mathrm{KCl}$ and $\mathrm{pH}$ in $\mathrm{H}_{2} \mathrm{O}$ of the soil was -1.08 (table 1) which indicates negative net surface charge. Further, estimated PZC value according to the equation proposed by Keng and Uphara, (1974) $\left(\mathrm{PZC}=2 \mathrm{pH}_{\mathrm{KCl}}-\mathrm{pH}_{\mathrm{H} 2 \mathrm{O}}\right)$ was 4.21.This also confirms that the PZC value of the soil could be around $\mathrm{pH} 4$. The variable charges in soils develop on the edges of lattice clay minerals and on the surface of sesquioxide, amorphous materials such as allophone imorgolite and organic matter (Karak et al., 2005). Negatively charge organic matter is contributing more to negative surface charges. Since soil is a mixture of different minerals, soil PZC value is determined by minerals which are having different PZC values and organic matter. Presence of minerals which are having lower PZC values; kaolinite (4.6), montmorillonite (2.5), feldspar (2.0-2.4), albite (2.0) $\mathrm{SiO}_{2}$ (2.0), and $\mathrm{MnO}_{2}$ (2.8) tends to reduce the point of zero charge in soils. Further Ogunwale and Isa, (2004) reported that PZC of soil tends towards lower value when organic matter content is high. In this soil, organic carbon content is low indicating high contribution of kaolinite for surface charge development. The lowering effect of kaolinite on PZSE is probably due to its edge single $\mathrm{OH}$ groups coordinated with $\mathrm{Si}^{4+}$, the silanol groups. Being more easily ionizable than the single $\mathrm{OH}$ groups coordinated with the $\mathrm{Al}^{3+}(\mathrm{AlOH})$ and to $\mathrm{Fe}^{3+}(\mathrm{FeOH})$, the silanol groups tend to only dissociate protons (Sparks, 1995). For this reason protonation of silanol groups takes place only at high $\mathrm{H}^{+}$concentration which contribute to lowering of PZSE in soil mainly with nonallophanic kaolinite. Further when soil become more weathered their 
PZSE values increase due to kaolinite destabilization and tend toward the soil $\mathrm{pH}$ values dropping the soil net surface charge to values near zero (Alves and Lavorenti, 2005).

The titration curves of the soil sample did not follow the usual trend of higher electrolyte concentration resulting in higher $\mathrm{pH}$ below the PZSE because at lower $\mathrm{pH}$ values protons were primarily consumed in the mineral dissolution reactions present in soils instead of generating surface charge (Appel et al., 2003, Karak et al., 2005). In order to explain the behavior of $0.001 \mathrm{M} \mathrm{KCl}$ titration curve further analysis is needed. However, an intersection point at $\mathrm{pH} 6.9$ indicates the presence of positive charges at colloidal surfaces, enabling soil to retain some anions.

\section{Phosphorus adsorption study}

Plot of the amount adsorbed against amount in solution (Fig. 3a) indicated that phosphorus adsorption increased with increasing phosphorus concentration in solution. In order to obtain maximum adsorption of phosphorus for the soil, data were transformed to fit the linear form of Langmuir adsorption isotherm (Fig. 3b) using the following equation.

$$
\frac{1}{q}=\frac{1}{q \max }+\frac{1}{k q \max } \frac{1}{c}
$$

where $\mathrm{c}$ is the final concentration after adsorption has occurred $\left(\mathrm{mg} \mathrm{L}^{-1}\right), \mathrm{q}$ is the amount of $\mathrm{P}$ adsorbed $\left(\mathrm{mg} \mathrm{kg}^{-1}\right), \mathrm{q}_{\max }$ is the adsorption maximum $\left(\mathrm{mg} \mathrm{kg}^{-1}\right)$ and $\mathrm{k}$ is a coefficient related to the bonding energy.

Conformity to the linear form of the Langmuir equation was observed for $\mathrm{P}$ adsorption with $\mathrm{r}^{2}=0.99(\mathrm{p}<0.001)$. Therefore, using the linear adsorption equation adsorption maximum $\left(\mathrm{q}_{\max }\right)$ calculated was $14285 \mathrm{mg} \mathrm{kg}^{-1}$.

According to adsorption data, this soil is having high phosphorus adsorption capacity indicating high potential to adsorb phosphate ions. It indicates when runoff water detach soil colloids and transport $\mathrm{P}$ enriched soil particles to surface water bodies that could result environmental problems, such as eutrophication.
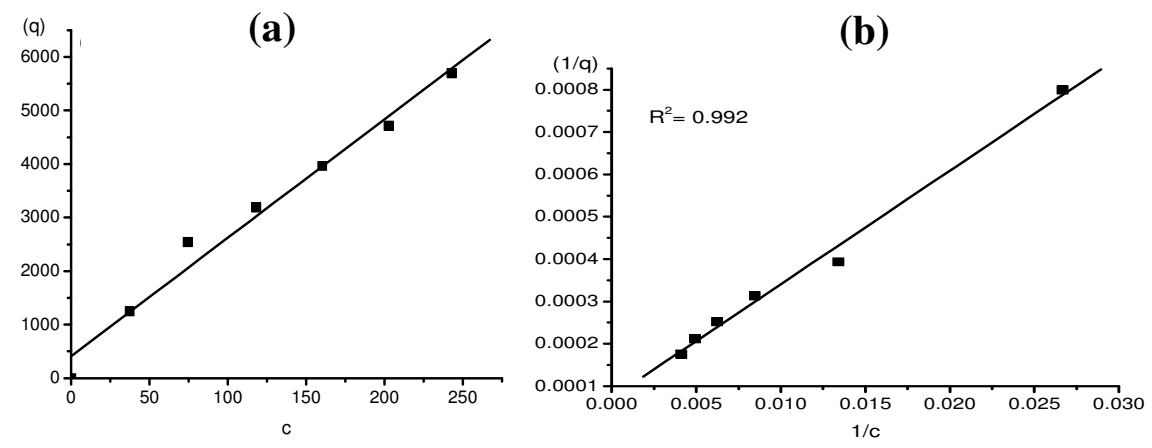

Fig. 3. Amount of $\mathbf{P}$ adsorbed against increasing solution $\mathbf{P}$ concentrations (a) and linear form of the Langmuir adsorption isotherm (b) ( $q=$ amount adsorbed, $\mathrm{mg}$ $\mathrm{kg}^{-1} ; \mathrm{c}=$ equilibrium concentration, $\mathrm{mg} \mathrm{L}^{-1}$ ). 


\section{CONCLUSIONS}

Studied soil shows a moderate retention ability of cations attributed to poor organic carbon content and low-activity clay mineralogy. Therefore, adaptation of proper organic matter management practices can minimize the loss of cations from soil and thereby minimize nutrient depletion due to leaching. Unlike many of the soils in dry zone, salinity is not a major problem in this location. Available and total metals concentrations in soil are below the threshold levels to cause any toxicities. Point of zero charge of the soil suggests that with the soil $\mathrm{pH}$ of 6.39 cations could be exchanged and become important in metal transport from soil to other ecosystems. Adsorption maximum of $\mathrm{P}$ in the soil is high indicating $\mathrm{P}$ deficiency as a main agronomic limitation of this soil. However, it has a potential for $\mathrm{P}$ enrichment with long term application of phosphorus fertilizers. Thus, measures are needed to increase the CEC and minimize erosion to prevent eutrophication in surface water bodies. Since this soil has not been cultivated for about four years, it could be used as a reference or model soil to monitor impacts due to agricultural practices in other soils in the area.

\section{ACKNOWLEDGEMENT}

Authors wish to acknowledge the National Research Council for the funding granted to carry out the research (NRC 11_66). Sri Lanka Institute of Nano Technology is highly appreciated for XRD analysis.

\section{REFERENCES}

Ajayi,S.O., Odesanya, B.O., Avwioroko, A.O., Adebambo, G.S. and Okafor, B. (2012). Effects of long term fertilizer use on trace metal levels of soils in a farm settlement. Journal of Agricultural Research and Development. 2, 44-51.

Akinremi, O.O., Flaten, D.N. and Ige, D.V. (2007). Direct and indirect effects of soil properties on phosphorus retention capacity. Soil Science Society of America Journal. 71, 95-100.

Alves, M.E. and Lavorenti, A. (2005). Point of zero salt effect; relationship with clay mineralogy. Pedosphere.15,545-553.

Appel, C., Ma, L.Q., Rhue, R.D and Kennelley, E. (2003). Point of zero charge determination in soils and minerals via traditional methods and detection of electroacoustic mobility: Geoderma. 113, 77-93.

Bandara, W.M.Y. (2007). Micronutrients in soil. pp. 93-102. In: Dharmakeerthi, R.S., Indraratne, S.P. and Kumaragamage, D. (Ed.) Manual of soil sampling and analysis. Special publication No.10, Soil Science Society of Sri Lanka. Asliya printers, Kurunegala.

Chaney, R.L. (1973). Crop and food chain effects of toxic elements in sludges and effluents; Proceedings of the Joint Conference on 'Recycling Municipal Sludges and Effluents on 
Land. National Association of State Universities and Land-Grant Colleges, Washington DC. 129-141.

Daniel, T.C., Sharpley, A.N. and Lemunyon, J.L. (1998). Agricultural Phosphorus and Eutrophication . A symposium overview. Journal of environmental quality. 27, 251-258.

Dimantha, S. (1994). Soil scientist should lead the land use planning in Sri Lanka. Journal of the Soil Science Society of Sri Lanka. 8, 1-15.

Essington, M.E. (2003).Soil and water chemistry. CRC Press, Boca Raton, Washington. pp. 334-348.

Indraratne, S.P. (2009). Soil amendments and fertilizers as sources and sinks of heavy metals. Journal of Soil Science Socity of Sri Lanka. 21, 1-15.

Indraratne, S.P. (2010). Mineralogy of the soils of Sri Lanka. pp. 59-78. In: Mapa, R.B., Somasiri, S. and Dassanayake, A.R. (Ed.) Soils of the dry zone of Sri lanka, Survodaya Vishva Lekha, Sri Lanka.

Kabata-Pendias, A., Pendias, H. (2001).Trace elements Soils Plants. CRC press. New York

Karak, K.T., Das, D.K., Singh, U.K. and Maiti, D. (2005). Influence of pH on soil charge characteristics and cadmium sorption in some noncontaminated soils of Indian subtropics. The scientific world journal. 5, 183-194.

Keng, J.C.W. and Uphara, G. (1974). Chemistry mineralogy and taxonomy of oxisoil and Ultisols proceeding of soil and crop science socity. 33, 119-126.

Kumaragamage, D. and Kendaragama, K.M.A. (2010). Risk and limitations of dry zone soils. pp. 239-258. In: Mapa, R.B., Somasiri, S. and Dassanayake, A.R. (Ed.) Soils of the dry zone of Sri lanka, Survodaya Vishva Lekha, Sri Lanka.

Kunze, G.W. and Dixon, J.B. (1986).Pre treatment for mineralogical analysis. In: Klute, A (Ed.) methods of soil analysis part 1. Agronomy society of America and soil science society of America. Madison, Wisconsin.

Manna, M.C., Swarup, A., Wanjari, R.H., Ravankar, H.N., Mishra, B., M.N. Saha, Singh Y.V., Sahi, D.K. and Sarap, P.A. (2005). Long-term effect of fertilizer and manure application on soil organic carbon storage, soil quality and yield sustainability under subhumid and semi-arid tropical India. Field Crop Research. 93, 264-290.

McGrith, D and McCormack,R.L. (1999). The significance of heavy metal and organic micro pollutant is soils. Johnstown castel Res. Centre, Wexford,Ireland. pp. 278.

McLaughlin, M.J., Hamon, R.E., McLaren, R.G., Speir, T.W. and Rogers S. L. (2000). A bioavailability-based rationale for controlling metal and metalloid contamination of agricultural land in Australia and New Zealand. Aust. J. Soil Res. 38, 1037-1086.

Mico, C., Recatala, L., Peris, M. and Sanchez, J. (2006). Assessing heavy metal sources in agricultural soils of an European Mediterranean area by multivariate analysis. Chemosphere. $65,863-872$. 
Morais, F.I., Page, A.L. and Lund, L.J. (1976). The effect of pH, salt concentration and nature of electrolytes on the charge characterization of Brazilian tropical soils. Soil Sci. Soc. Am. J. 40, 521-527.

Naindu, R., Kookana, R.S., Summer, M.E., Harter, R.D. and Tiller, K.G. (1997). Cadmium sorption and transport in variable charge soils. J.Environ. Qual. 26, 602-617.

Nelson, D.W. and Sommer L.E. (1996). Total organic carbon and organic matter. pp. 361404. In: Sparks, D.L. (Ed.) Method of Soil Analysis, Part 3, Chemical Methods: American Society of Agronomy, soil science society of America, Madiston, Wiscons, USA.

Ogunwale,J.A. and Isa, N. (2004). Determination of zero point of charge in selected soils of the southern guinae savanna of Nigeria. J. Agric. Res. \& Dec, 3, 105-112.

Parham, J., Deng, S., Raun, W.and Johnson, G. (2002). Long-term cattle manure application in soil. Biology and fertility of soils.35, 328-337.

Premararhna, H.M.P.1., Hettiarachchi, G.M. and Indraratne, S.P. (2010). Trace metal concentration in crops and soils collected from intensively cultivated areas of Sri Lanka. Pedologist. 53, 230-240.

Sharpley, A and Tunney, H. (2000). Phosphorus research strategies to meet agricultural and environmental challenges of the $21^{\text {st }}$ century. Journal of environmental quality. 29, 176-181.

Sinitsyn, V.A., Aju, S.U. Kulik, D.A. and Wood, S.A. (1999). Acid-base surface chemistry and sorption of some lanthanides on K-saturated Marblehead illite: I. Results of an experimental investigation, Geochimica et Cosmochimica Acta. 64, 185-194

Somasiri, S. (1984). Wet Alfisols of Sri Lanka, Proceedings of the Annual session of the Soil Science Soceity of Sri Lanka, pp. 35-55.

Sparks, D.L. (1995). Environmental soil chemistry.acadamic press,San diego P 267.

Sposito, G., Hotzclaw, K.M., LeVesque-Madore C.S. and Johnston, C.T. (1982). Trace-metal chemistry in arid-zone field soils amended with sewage-sludge. Comparative study of the fulvic acid fraction. Soil Sci. Soc. Am. J. 46, 265-270.

Stacey,S,P., McLaughlin, M.J. and. Hettiarachchi,G.M. (2010) Fertilizer-Borne Trace Element Contaminants in Soils. pp. 135-154. In. Hooda, P.S. (Ed.) bookTrace metals in soils. Antony Rowe Ltd, Chippenham, Wiltshire.

Summer, M.E. and Miller, W.P. (1996). Cation exchange capacity and exchange coefficient. pp. 1201-1229. In: Sparks, D.L. (Ed.) Method of soil science analysis, part 3, chemical methods: American society of agronomy, soil science society of America, Madison, Wisconsin, USA,

Tan, K. H. (1994). Liquid Phase (In) Environmental soil science, Marcel dekker,Inc, New york, pp.138-141. 
Tu, C., Zheng,C.R. and Chen, H.M. (2000). Efect of applying chemical fertilizers on forms of lead and cadmium in red soil. Chemosphere 41,133-138.

Yu, T.R., Sun, H.Y. and Zhang, H. (1997) Specefic adsorption of cations. pp 140-174.In: Yu, T.R. (Ed.) chemistry of variable charge soils. Oxford university press, New York.

Zhao, A.Z. and Zhang, X.N.(1997). Effect of phosphate adsorption on positive and negative charges of variable charge soils. Acta Pedologica Sinica 34, 123-129. 